УДК 657.1.012

DOI: https://doi.org/10.37320/2415-3583/8.7

Тюленсва Ю.В.

кандидат економічних наук, доцент кафедри економіки і підприємництва,

Національний технічний університет Украӥни

«Київський політехнічний інститут імені Ігоря Сікорського»

\title{
ІДЕНТИФІКАЦІЯ РИЗИКІВ ПІДПРИЕМСТВА В ПРОЦЕСІ ОЦІНЮВАННЯ ВАРТОСТІ
}

Метою статті було дослідження можливостей врахування ризику у процесі оцінювання вартості підприємства. Розглянуто місие оцінки ризику в прочесі оцінювання вартості підприємства. Лише один із запропонованих підходів прямо визначає значення ризику та його вплив на вартість, а саме дохідний, решта підходів опосередковано зазнає впливу ризиків на вартість підприємства. Надано перелік методик визначення значення ризику в розрізі застосування дохідного підходу за рахунок встановлення ставки дисконтування. 3'ясовано та подано сутність аналізу фінансового стану підприємства, основних показників, що його визначають, для подальшого застосування ичих величин в аналітичній роботі. Визначено, щзо найкращчим методом врахування ризику є метод кумулятивної побудови. Очінювання вартості підприємства повинна враховувати всі методи, щчо забезпечить врахування можливих джерел виникнення ризиків.

Ключові слова: ризики підприємства, ідентифікація ризиків, очінка вартості.

Постановка проблеми. Підприємство - це рушійна сила економіки, яка забезпечує процес задоволення потреб споживачів та створює передумови науково-технічного прогресу. Важливими для підприємства $є$ стан його конкурентоздатності та сталий розвиток, особливо в умовах ризику. Одним із важливих критеріїв визначення цих показників $є$ його вартість, оскільки вона віддзеркалює стан фінансових показників та зацікавленість різних учасників ринку. Результати діяльності підприємств $є$ непередбаченими, невизначеними та важко прогнозованими в результаті дії ризику. Прагнення отримати позитивні результати стимулює підприємців створювати засади управління невизначеністю саме на рівні врахування ризику у діяльності підприємства, а вчених - формувати теоретичні та методологічні основи цих заходів. Іноземні вчені створили теорію ризикології з урахуванням умов та особливостей економіки саме їх країн [1-5].

Оцінка вартості підприємства є одним з ключових параметрів під час вирішення стратегічних питань управління підприємством, отже, повинна враховувати вплив ситуації ризику на діяльність підприємства.

Аналіз останніх досліджень i публікацій. У сучасній економічній теорії 3 питань оцінювання вартості підприємства переважають роботи іноземних науковців, таких як А. Дамадаран, Ф. Модельяні, М. Міллер, 3. Боді, Р. Мертон, Ш.П. Пратт, Дж. Муррин, А. Раппапорт, Дж. Стюарт, К. Уолт, Дж. Фрідман, Г.С. Харрісон, Дж. Харвей, Дж. Хікс, Дж. ван Хорн, У. Шарп, Р. Бранденбург, де розглядаються теоретичні та методологічні положення, які сформовані та використовуються в країнах з розвиненою ринковою економікою. Водночас останнім часом питанням оцінювання вартості підприємства приділяють увагу вітчизняні науковці, які досліджують ії в умовах економіки, що розвивається. Серед них можна виділити таких, як Г.І. Башнянин, М.I. Бондар, С.В. Валдайцев, В.В. Григор'єв, А.Г. Грязнова, Г.В. Козаченко, М.В. Корягін, Л.А. Костирко, В.М. Костюченко, О.Г. Мендрул, О.А. Сарапін, Н.В. Тертична, М.А. Федотова, Л.М. Худолій, М.Г. Чумаченко, А.А. Чухно, В.А. Щербаков, Н.М. Якупов, І.Й. Яремко.

Мета статті. Розробки іноземних учених не завжди відповідають вимогам сучасного розвитку економіки України. Закладення основ управління ризиками підприємства має будуватися на основах методик та методологій, розроблених іноземними вченими з урахуванням специфіки розвитку економіки України. Метою статті $\epsilon$ розгляд основ врахування ризику у процесі оцінювання вартості підприємства.

Виклад основного матеріалу. Оцінка вартості підприємства є одним 3 найбільш важливих аспектів фінансів підприємства. Складність оцінювання вартості підприємства пов'язана 3 використанням різного методологічного апарату оцінювання, різноманітністю об'єктів оцінювання, багатообразністю та неоднорідністю завдань оцінювання.

Підприємство поєднує велику кількість активів, серед яких слід назвати основні та оборотні засоби, нематеріальні активи, зокрема права власності, товарні знаки, патенти та гудвіл.

Необхідність оцінювання вартості підприємства виникає за різних обставин, серед яких можна виокремити такі цілі та завдання проведення оцінювання вартості підприємства [6]: 
- купівля-продаж підприємства цілком або по частинам;

- купівля-продаж акцій підприємства;

- розроблення плану розвитку підприємства;

- визначення кредитоспроможності підприємства й вартості застави в процесі кредитування;

- страхування;

- визначення бази оподаткування;

- переоцінка основних активів підприємства;

- реструктуризація (злиття, поглинання, розділення) або ліквідація підприємства;

- визначення санаційної спроможності;

- виконання інвестиційного проєкту розвитку підприємства;

- додаткова емісія акцій;

- залучення зовнішнього фінансування;

- майнові спори;

- приватизація;

- оптимізація структури майнового комплексу підприємства;

- формування статутного капіталу;

- підвищення ефективності поточного управління підприємством.

Незважаючи на особливості оцінювання вартості в кожному наведеному випадку, іiі проведення базується на тому, що підприємство є товаром 3 характерними для нього властивостями [7].

Врахування ризиків у процесі оцінювання $\epsilon$ необхідним для отримання максимально достовірної інформації, оскільки вартість є індикатором стабільного розвитку підприємства, а процес ідентифікації ризиків є важливим для ефективної діяльності підприємства. Задля визначення вартості підприємства необхідно ідентифікувати ризик та сукупність факторів, що впливають на вартість, а також визначити вплив кожного конкретного фактору.

3 усієї сукупності методів оцінювання вартості підприємства лише дохідний підхід враховує наявність ризиків та їх вплив на значення оцінювання вартості підприємства за рахунок розрахунку ставки дисконту. Ставка дисконту є відсотковою ставкою для коригування майбутньої вартості у теперішню й такою, що враховує розмір ризику підприємства.

В науковій літературі виділяють декілька шляхів розрахунку розміру ставки дисконтування залежно від наявної інформації в процесі оцінювання та цілі, для досягнення якої проводиться оцінювання вартості підприємства.

Перший підхід грунтується на використанні інформації фондового ринку про зміни дохідності вільних акцій. Таким чином, він $є$ оптимальним для визначення вартості підприємства, акції якого котируються на фондовій біржі. Для визначення вартості підприємства, яке не має можливості виходу на фондовий ринок, наприклад підприємства організаційно-правової форми «приватне акціонерне товариство» або «товариство 3 обмеженою відповідальністю», використовується коригування результату за допомогою знижки за недостатню ліквідність. Цей підхід визначення ставки дисконту називається моделлю оцінювання капітальних активів (Capital Asset Pricing Model) [8; 9].

Класична модель, сформована У. Шарпом [9], базувалась на врахуванні двох типів ризиків, які притаманні інвестиційній діяльності, а саме системного та несистемного ризику. Системний ризик - це сукупність ринкових ризиків, які не можуть бути диверсифіковані; до них належать зміни відсоткових ставок, спади економіки та війни. Несистемний ризик - це специфічний ризик, тобто індивідуальний ризик, який характерний для окремих акцій і може бути диверсифікований, оскільки не корелюється із загальними ринковими рухами.

САРМ-модель має такий загальний формалізований вигляд:

$$
R=r_{f}+\beta\left(r_{m}-r_{f}\right),
$$

де $\mathrm{R}$ - ставка дисконту; $\mathrm{r}_{\mathrm{f}}$ - безризикова ставка дохідності; $\mathrm{r}_{\mathrm{m}}$ - очікувана дохідність ринкового портфеля (фондовий індекс); $\beta$ - коефіцієнт «бета», тобто коефіцієнт системного ринкового ризику, який відображає чутливість дохідності акції до змін дохідності ринкового портфеля, пов'язаний зі станом макроекономічної та політичної ситуації в країні.

При цьому під безризиковою ставкою розуміється ставка, що відображає дохідність вкладу, не пов'язаного з ризиком, доходність таких вкладів відома заздалегідь, а ймовірність неотримання мінімальна [10, с. 205].

Всі види діяльності підприємства є ризиковими в сучасних умовах економіки, тому до такої ставки визначена низка таких вимог:

- дохідність на найбільш ліквідні активи 3 високою гарантією повернення;

- доступність для вкладника альтернативного варіанта вкладу.

Як безризикова ставка приймається ставка дохідності щодо державних цінних паперів 3 відповідним за періодом оцінювання терміном погашення.

У західній практиці безризикова ставка доходу визначається, як правило, на основі ставки доходу по довготермінових (понад 10 років) державних облігаціях. Такий вибір зумовлений тим, що довготермінові державні облігації характеризуються низьким рівнем ризику неплатоспроможності та високим ступенем ліквідності. Окрім того, під час визначення ставки доходу за цим видом цінних паперів враховується довготривалий вплив інфляції. Так, у європейських країнах номінальна ставка доходу по довготривалих урядових облігаціях терміном погашення 10 років перебуває в 
межах 4-8\% річних, а реальна (тобто з урахуванням інфляціi) - від 3,5\% до 4,5\% [6].

У державах 3 нестабільною грошовою одиницею та незбалансованим бюджетом описаний підхід застосувати неможливо, оскільки цінні папери деноміновані в національній валюті, а частка ризикової складової частини в нормі доходу по цих паперах дуже велика, тому безризикову ставку доходу в Україні можна визначати на основі:

- ставки безризикових активів західних країн плюс ризик України;

- ставки по короткотерміновим депозитам вітчизняних банків, деномінованих у вільно конвертовану валюту;

- ставки облігацій внутрішньої державної позики.

Перший спосіб є складним у реалізації, адже відсутня достовірна база для розрахунку. Другий також має недоліки, зокрема депозит не $є$ реальною альтернативою, адже також $є$ ймовірність втрати його з огляду на кризовий стан банківської системи. Відповідно до зазначених недоліків доцільніше використовувати ставку по облігаціям внутрішньої державної позики.

У сучасних умовах ця модель була розширена та дає можливість врахувати більш широкий спектр ризиків:

$$
R=r_{f}+\beta\left(r_{m}-r_{f}\right)+S_{1}+S_{2}+C,
$$

де $\mathrm{S}_{1}$ - премія для малих підприємств; $\mathrm{S}_{2}-$ премія за ризик, характерний для окремого підприємства; С - ризик країни.

Коефіцієнт «бета» розраховується з огляду на амплітуду коливань загальної прибутковості акцій конкретного підприємства порівняно із загальною прибутковістю фондового ринку загалом.

Загальна прибутковість розраховується як різниця між вартістю ринкової ціни на кінець та початку року, що збільшується на величину виплачених за період дивідендів, скоригованих на значення ринкової ціни на початок періоду.

Коефіцієнт «бета» у світовій практиці зазвичай розраховується шляхом аналізу статистичної інформації фондового ринку. Ця робота проводиться спеціалізованими фірмами. Дані про коефіцієнт «бета» публікуються в низці фінансових довідників і в деяких періодичних виданнях, які аналізують фондові ринки. Професійні оцінювачі, як правило, не займаються розрахунками коефіцієнта «бета». В нашій країні, на жаль, відсутня така система розрахунку, а коефіцієнт «бета» необхідно розраховувати індивідуально 3 використанням апарату статистики.

Для розрахунку коефіцієнта «бета» використовують таку формулу [11, с. 130]:

$$
\beta=\frac{K \cdot G_{s c}}{G_{i}},
$$

де $\mathrm{K}$ - ступінь кореляції між рівнем прибутковості звичайних акцій підприємства й середнім рівнем прибутковості фондового індексу в поточному періоді; Gsc - середньоквадратичне відхилення прибутковості звичайних акцій підприємства в аналізованому періоді; Gi - середньоквадратичне відхилення дохідності фондового індексу в досліджуваному періоді.

В умовах, коли для розрахунку коефіцієнта «бета» не вистачає статистичних даних, можна скористатися середньогалузевими значеннями або наближеним підходом, запропонованим М.А. Лімітовским, заснованим на виявленні факторів фінансового ризику та експертної оцінки ступеня їх прояву в аналізованому періоді $[14$, с. 156$]$.

Іншим методом розрахунку ставки дисконту $є$ метод кумулятивної побудови (build-upmethod), заснований на використанні такої формули:

$$
R e_{a}=r_{f}+\sum_{i=1}^{n} \mathrm{IRi},
$$

де $\mathrm{r}_{\mathrm{f}}$ - безризикова ставка дохідності; $\mathrm{i}$ - номер фактору ризика властивого бізнесу, що враховується; n - кількість факторів ризику, що враховуються; IRi - надбавка (премія) за ризик, обумовлений дією фактору i.

Кількість факторів ризику й відповідна величина поправки для методу кумулятивної побудови визначається, як правило, методом експертної оцінки, який краще проводити за рахунок опитування управлінського персоналу підприємства (табл. 1).

Більш докладно запропоновані фактори ризику можна розглянути таким чином:

1) розмір підприємства $є$ найбільш очевидною перевагою, яку має велике підприємство;

Таблиця 1 - Приклад визначення премії за ризик для методу кумулятивної побудови

\begin{tabular}{|l|c|}
\hline \multicolumn{1}{|c|}{ Вид ризику } & Діапазон визначення премії за ризик, \% \\
\hline Розмір підприємства & $0-3$ \\
\hline Фінансова структура & $0-5$ \\
\hline Виробнича та територіальна диверсифікація & $0-3$ \\
\hline Диверсифікація клієнтури & $0-4$ \\
\hline Рентабельність підприємства та прогнозованість його доходів & $0-4$ \\
\hline Якість управління & $0-5$ \\
\hline Інші власні ризики & $0-3$ \\
\hline
\end{tabular}


він полягає у відносно більш легкому доступі на фінансові ринки, а також більшій стабільності діяльності порівняно з малими конкурентами;

2) фінансова структура складається з власних і запозичених коштів у певному співвідношенні, що визначається аналізом таких фінансових коефіці$є н$ нів, як коефіцієнт автономії, частка довгострокової заборгованості в пасиві балансу, частка кредиторської заборгованості, коефіцієнти ліквідності;

3) виробнича й територіальна диверсифікація визначає виробництво товарів і надання послуг підприємством, що належать до різних галузей території;

4) диверсифікація клієнтури передбачає, що, згідно $з$ теорією маркетингу, мета підприємства полягає у задоволенні потреб клієнтів; чим більше у підприємства споживачів, тим за інших рівних умов більш стійке підприємство, однак рівень диверсифікації визначається не тільки кількістю клієнтів, але й часткою збуту, що припадає на кожного 3 них; чим менше нерівність частки виручки, яка припадає на конкретних клієнтів, тим за інших рівних умов менше залежність підприємства від конкретного споживача;

5) якість управління відбивається на всіх аспектах існування підприємства, тобто поточний стан підприємства й перспективи його розвитку багато в чому зумовлені якістю управління.

Кумулятивний метод має як переваги, так i недоліки. До головних недоліків можна віднести суб'єктивність оцінок щодо різних ризиків конкретного об'єкта оцінювання та розмитість обліку інших ризиків. Проте, незважаючи на ці недоліки, перевага цього методу порівняно з іншими полягає у відносно детальному обліку основних факторів ризику, пов'язаних з конкретним підприємством, а також цей метод доцільно використовувати для аналізу вартості підприємства, що функціонує в економіці зі слабо розвинутим фондовим ринком, або для підприємства, яке не може брати участь у лістингу.

Наступним методом оцінювання дисконту $\epsilon$ арбітражна теорія ціноутворення. Ця теорія передбачає, що дохідність власного капіталу розраховується 3 урахуванням факторів, що на неї впливають [12]:

$$
R=\lambda_{0}+\lambda_{1} \beta_{1}+\lambda_{2} \beta_{2}+\ldots+\lambda_{\mathrm{n}} \beta_{\mathrm{n}},
$$

де $\lambda_{0}$ - дохідність безризикових вкладів; $\lambda_{\mathrm{i}}-$ премія за ризик, що обумовлений відповідним фактором; $\beta_{\mathrm{i}}$ - чуттєвість очікуваної дохідності на зміну значення відповідного фактору ризику; $\mathrm{n}$ кількість факторів ризику.

Наступною методикою визначення ставки дисконту є трьохфакторна модель Фамі-Френча. Вона передбачає, що дохідність власного капіталу залежить від трьох факторів, а саме ринкового індексу, розміру капіталізації, співвідношення балансової (різниця між вартістю активів та зобов'язань) та ринкової вартості (за капіталізацією акцій) [13]:

$$
R=r_{f}+b_{i} E R P+s_{i} S M B P+h_{i} H M L P,
$$

де $\mathrm{r}_{\mathrm{f}}$ - безризикова ставка дохідності; $b_{\mathrm{i}}-$ коефіцієнт регресії по фактору премії за ринковий ризик; ERP - очікувана премія за ринковий ризик; $\mathrm{s}_{\mathrm{i}}$ - коефіцієнт регресії за фактором розбіжності дохідності малих і великих підприємств; SMBP премія за розмір капіталу компаніï; hi - коефіцієнт регресії по фактору «балансова вартість - ринкова вартість»; HMLP - розбіжність дохідності акцій 3 високим та низьким коефіцієнтом «балансова вартість - ринкова вартість».

Існує також метод розрахунку ставки з використанням методу середньозваженої вартості капіталу (WACC). Цей метод використовується, коли необхідно визначити вартість капіталу, який отримано з різних джерел, тобто в основі аналізу не лише лежить власний капітал, але й відбувається інвестування в діяльність підприємства. Однак ця методика не враховує наявності ризиків у діяльності підприємства, іiі мета полягає у визначенні доцільності інвестування.

Висновки. Отже, в процесі дослідження методів оцінювання вартості підприємства встановлено, що єдиним підходом, який враховує систему ризиків підприємства, є дохідний. Всі можливі шляхи визначення рівня ризику показали, що основою розрахунку $є$ ставка дисконтування. Найбільш доречною ставкою дисконту 3 урахуванням ризиків в процесі оцінювання вартості є використання методу кумулятивної побудови. Його використання цілком відповідає вимогам ринкового підходу до оцінюівння підприємства, що гарантує більш повне формування інформації для прийняття управлінських рішень та підкреслює доцільність прийняття рішень на основі вартісного підходу.

Однак оцінювання вартості підприємства має враховувати всі методи, що забезпечить врахування можливих джерел виникнення ризиків.

\section{Список використаних джерел:}

1. Шумпетер Й. Теория экономического развития (исследование предпринимательской прибыли, капитала, процента и цикла конъюнктуры). - Москва : Прогресс, 1982. 455 с.

2. Природа фирмы: к 50-летию выхода в свет работы Р. Коуза «Природа фирмы» / [Центр эволюционной экономики] ; под ред. О.И. Уильямсона, С.Дж. Уинтера ; пер. с англ. М.Я. Каждана ; науч. ред. пер. В.Г. Гребенников. Москва : Академия народного хозяйства при Правительстве Российской Федерации ; Дело, 2001. 360 c. (Translation Projekt. Программа Центрально-Европейского Университета / [редкол.: Л.И. Абалкин (гл. ред.) и др.]). 
3. Ткаченко Т.П. Підприємництво як основа формування середнього класу в Україні (організаційно-управлінські засади) : автореф. дис. ... канд. екон. наук : спец. 08.00.03 «Економіка та управління національним господарством» ; Інститут законодавства Верховної Ради України. Київ, 2008. 23 с.

4. Кузьмін О.Є., Вербицька Г.Л., Глібчук В.М. Управління інвестиційними ризиками підприємства (на прикладі машинобудування) : монографія. Івано-Франківськ : Галицька академія, 2008. 160 с.

5. Лернер Ю.И. Бизнес-планирование предпринимательской деятельности в условиях неопределенности и рисков. Харьков : Фактор, 2006. 480 с.

6. Калініна О.М., Божко Е.А. Оцінка вартості підприємства в сучасних умовах. Економіка та управління підприємствами машинобудівної галузі: проблеми теорії та практики. 2010. № 2 (10). С. 43-50.

7. Корягін М.В. Підходи до визначення поняття вартості підприємства та їх розвиток. URL: http://archive.nbuv.gov.ua/ portal/natural/vnulp/menegment/2012_722/23.pdf.

8. Хаустова В.Є., Матюшенко О.І. Методологічні засади оцінки вартості підприємства. Проблеми економіки. 2009. № 4. C. 57-76.

9. Sharpe W. Capital Asset Prices: A Theory of Market Equilibrium Under Conditions of Risk. Journal of Finance. 1964. № 19. Р. 425-442.

10. Брейли Р., Стюарт М. Принципы корпоративных финансов / пер. с англ. Н.В. Барышниковой. Москва : ЗАО «Олимп-Бизнес», 2008. 1008 с.

11. Бланк И.А. Управление финансовыми рисками. Киев : Ника-Центр, 2005. 600 с.

12. Беляева А.В., Воронцовский А.В. Арбитражная теория ценообразования (на примере фондового рынка Великобритании). Вестник СПбГУ. 1988. Сер. 5. № 4 (26). С. 73-82.

13. Рутгайзер В.М. Оценка стоимости бизнеса : учебное пособие. Москва : Маросейка, 2007. 448 с.

14. Лимитовский М.А. Инвестиции на развивающихся рынках. Москва : Дека, 2002. 304 с.

\section{References:}

1. Shumpeter, Y. (1982) Teoriya e 'konomicheskogo razvitiya (issledovanie predprinimatel'skoj priby'li, kapitala, proczenta i czikla kon'yunktury'). M. : Prohress.

2. Priroda firmy': K 50-letiyu vy'khoda v svet raboty' R. Kouza “Priroda firmy'”, (2001). M. : Akad. nar. khoz-va pry Pravytelstve Ros. Federatsyy ; Delo.

3. Tkachenko, T.P. (2008). Pidpryiemnytstvo yak osnova formuvannia serednoho klasuv Ukraini (orhanizatsiino-upravlinski zasady) : avtoref. dys. na zdobuttia stupenia kand. ekon. nauk : spets. 08.00 .03 "Ekonomika ta upravlinnia natsionalnym hospodarstvom". K.

4. Kuzmin, O.I. (2008). Upravlinnia investytsiinymy ryzykamy pidpryiemstva (na prykladi mashynobuduvannia) : [monohrafia]. Ivano-Frankivsk : Halytska akademiia, 2008. - $160 \mathrm{~s}$.

5. Lerner, Yu.Y. (2006) Byznes-planyrovanye predprynymatelskoi deiatelnosty v uslovyiakh neopredelennosty y ryskov. Kh. : Faktor.

6. Kalinina, O.M., Bozhko, E.A. Otsinka vartosti pidpryiemstva v suchasnykh umovakh. (2010). Ekonomika ta upravlinnia pidpryiemstvamy mashynobudivnoi haluzi: problemy teorii ta praktyky. № 2 (10). S. 43-50.

7. Koriahin, M.V. Pidkhody do vyznachennia poniattia vartosti pidpryiemstva ta yikh rozvytok [Elektronnyi resurs]. Retrieved from: http://archive.nbuv.gov.ua/portal/natural/vnulp/menegment/2012_722/23.pdf.

8. Khaustova, V.I., Matiushenko, O.I. (2009) Metodolohichni zasady otsinky vartosti pidpryiemstva. Problemy ekonomiky. № 4.

9. Sharpe, W. (1964) Capital Asset Prices: A Theory of Market Equilibrium Under Conditions of Risk. Journal of Finance. № 19.

10. Breily, R., Maiers S. (2008). Princzipy'korporativny'kh finansov. M. : ZAO “Olymp-Byznes”.

11. Blank, Y.A. (2005). Upravlenie finansovy'mi riskami. K. : Nyka-Tsentr.

12. Beliaeva, A.V., Vorontsovskyi, A.V. (1998) Arbytrazhnaia teoriia tsenoobrazovanyia (na prymere fondovoho rynka Velykobrytanyy). Vestnyk SPbHU. Ser. 5. № 4 (26).

13. Ruthaizer, V.M. (2007). Otsenka stoymosty byznesa : uchebnoe posobye. M. : Maroseika.

14. Lymytovskyi, M.A. (2002) Investiczii na razvivayushhikhsya ry'nkakh. M. : Deka. 
Tiulenieva Yuliia

National Technical University of Ukraine "Igor Sikorsky Kyiv Polytechnic Institute"

\section{IDENTIFICATION OF ENTERPRISE RISKS IN THE VALUE ASSESSMENT PROCESS}

The purpose of this article was to investigate the possibility of considering risk in the process of valuing an enterprise. The reasons and the essence of carrying out the valuation of the enterprise are analyzed. The main place of risk assessment in the process of valuation of the enterprise is considered. Only one of the proposed approaches directly determines the value of risk and its impact on value - profitable, the other approaches indirectly influences the risk on the value of the enterprise. A list of techniques for determining the value of risk in the context of applying the income approach by setting a discount rate is given. It is analyzed the essence of the methods and their main advantages and disadvantages are considered. The discount rate is based on the risk-free rate of return. The article analyzes the sources of obtaining the risk-free discount rate; in particular, its basis is the rate of return on government securities with maturity corresponding to the valuation period. It is determined that in countries with unstable currency and unbalanced budget, this approach is impossible to apply, as securities are denominated in national currency and the share of the risk component in the rate of return on these securities is very large. The possibility of using alternatives to determine the risk-free rate, their advantages and disadvantages, is analyzed. Features of consideration of different sources of risk are determined. Sensitivity is the basis for taking risk into account - the reaction of a stock or other object to the influence of certain factors, which improves the coverage of sources of risk. The essence and the analysis of the financial state of the enterprise, the main indicators that determine it, are explained and presented for the further application of these values in the analytical work. The author proved and distinguished one of the methods that fully meet the requirements of the market approach of enterprise valuation, namely the method of cumulative construction. The number of risk factors and the corresponding amount of the correction for the cumulative construction method are usually determined by the peer review method, which is best done through a survey among the management staff of the enterprise. The cumulative completion method covers key enterprise lines and enterprise characteristics, including enterprise size, financial structure, production and territorial diversification, client diversification, quality of management, and other specific factors. Valuation of the enterprise should take into account all methods, which in turn will ensure that possible sources of risk are taken into account.

Key words: enterprise risks, risk identification, cost estimation.

JEL classification: G32. 